\title{
TRANSFORMASI DIGITAL WAKAF BWI DALAM MENGHIMPUN WAKAF DI ERA DIGITALISASI
}

\author{
Rahmawati $^{1}$, Husni Thamrin ${ }^{2}$, Satriak Guntoro ${ }^{3}$ \& Sri Kurnialis ${ }^{4}$ \\ Prodi Ekonomi Syari'ah, Program Pascasarjana UIN Sultan Syarif Kasim Riau \\ Email :22190323212@students.uin-suska.ac.id, husni2017husni@gmail.com, \\ 22190313542@students.uin-suska.ac.id,22190324702@students.uin-suska.ac.id
}

\begin{abstract}
ABSTRAK
Tulisan ini membahas transformasi digital wakaf BWI dalam menghimpun wakaf di era digitalisasi. Permasalahan yang sering terjadi yakni teknologi dan platform digital yang tersedia belum dimanfaatkan secara efektif dan efisien dalam penghimpunan dana wakaf. Permasalahan tersebut harus ditemukan solusi dalam mengatasinya. Upaya yang dilakukan antara lain inovasi teknologi untuk memaksimalkan penghimpunan wakaf di berbagai lini masyarakat. Rumusan masalah pada penelitian ini yakni bagaimana transformasi digital wakaf BWI dalam menghimpun wakaf di era digitalisasi. Penelitian ini bersifat penelitian kepustakaan (library research) ) dengan metode tematik. Hasil pembahasan yakni transformasi digital yang dilakukan oleh BWI untuk memperkuat ekosistem pembangunan wakaf nasional yakni dengan mendorong penguatan transformasi digital sebagai langkah strategis dalam upaya optimalisasi potensi wakaf. Ada tiga tahapan proses transformasi digital yang dilakukan BWI. Pertama, penguatan digitalisasi internal BWI. Kedua, memperkuat digitalisasi nazhir dan integrasi data wakaf. Ketiga, mengakselerasi penguatan ekosistem digital dan pengembangan inovasi model pengelolaan wakaf secara digital. Dengan memaksimalkan upaya melalui tiga tahapan di atas, diharapkan ekosistem digital wakaf akan semakin fleksibel, membesar dan menguat, serta memberikan dampak multiplier terhadap perekonomian nasional.
\end{abstract}

Kata Kunci : Transformasi, Penghimpunan, Digitalisasi Wakaf.

\begin{abstract}
This paper discusses the digital transformation of BWI waqf in collecting waqf in the digitalization era. The problem that often occurs is that the available digital technology and platforms have not been used effectively and efficiently in collecting waqf funds. This problem must be found a solution in overcoming it. Efforts made include technological innovation to maximize waqf collection in various lines of society. The formulation of the problem in this study is how the digital transformation of BWI waqf in collecting waqf in the digitalization era. This research is library research with thematic method. The results of the discussion are the digital transformation carried out by BWI to strengthen the national waqf development ecosystem, namely by encouraging the strengthening of digital transformation as a strategic step in optimizing the potential of waqf. There are three stages of the digital transformation process carried out by BWI. First, strengthening BWI's internal digitization. Second, strengthen the digitization of nazhir and the integration of waqf data. Third, accelerate the strengthening of the digital ecosystem and the development of innovative digital waqf management models. By maximizing efforts through the three stages above, it is hoped that the digital waqf ecosystem will be more flexible, enlarged and strengthened, and will have a multiplier impact on the national economy.
\end{abstract}

Keywords: Transformation, Collection, Digitization of Waqf. 


\section{PENDAHULUAN}

Wakaf merupakan salah satu ajaran di dalam agama Islam. Pentingnya penelitian lanjut tentang wakaf disebabkan karena wakaf mencakup pembahasan yang luas, bukan hanya urusan ibadah melainkan juga urusan muamalah. Wakaf merupakan bentuk ketaatan seorang hamba kepada Allah SWT. Namun lebih dari itu wakaf merupakan bentuk kepedulian sosial seorang muslim kepada masyarakat sekitarnya. Khususnya dalam tujuannya meningkatkan kualitas masyarakat dalam berbagai aspek kehidupan (M Paksi, 2020).

Perkembangan wakaf di Indonesia kian hari kian meningkat. Hal ini terlihat dari bertambahnya jumlah dan objek harta wakaf, baik berupa tanah, uang dan lainnya, yang tersebar di berbagai penjuru di Indonesia (Fauzia et al, 2019).

Digitalisasi yang terus masuk dan mengubah pola hidup (life style) masyarakat menuntut lembaga untuk peka dalam memberikan skema penghimpunan dana wakaf yang mudah 1,9 miliar Muslim di dunia. Indonesia sendiri memiliki jumlah Muslim terbesar di dunia dengan persentase $87.2 \%$ dari jumlah penduduknya, sehingga diperkirakan ada 229 juta umat Muslim di Indonesia (IBTimes.ID, 2020).

Fatwa Majelis Ulama Indonesia tentang Wakaf Uang pada 11 Mei 2002. Wakaf uang (waqf al-nuqud) dalam fatwa tersebut diartikan sebagai wakaf yang dilakukan seseorang, kelompok orang, lembaga atau badan hukum dalam bentuk uang tunai. Fleksibilitas benda wakaf juga menjadi kunci utama dalam penghimpunan dana wakaf. Wakaf uang pada akhir-akhir ini menjadi tren untuk berwakaf dikarenakan lebih mudah dan fleksibel.

BWI terus melakukan transformasi digital wakaf di Indonesia yang sigap terhadap tuntutan tersebut. Pada tanggal 1 Juli 2021 lalu Badan Wakaf Indonesia (BWI) meluncurkan e-services untuk para nazhir di Indonesia dalam bentuk layanan elektronik untuk pendaftaran nazhir. Layanan ini diluncurkan sebagai bagian dari fase kedua dari tahapan proses transformasi digital yang dilakukan oleh BWI untuk memperkuat ekosistem pembangunan wakaf nasional.

\section{TINJAUAN PUSTAKA}

\section{Konsep Transformasi Digital}

Transformasi digital adalah bagian dari proses teknologi yang lebih besar. Transformasi digital merupakan perubahan yang berhubungan dengan penerapan teknologi digital dalam semua aspek kehidupan masyarakat. Transformasi digital adalah tahap ketiga dalam alur teknologi digital sebagaimana tampak pada alur berikut:

\section{Kompetensi digital}

2. Penggunaan digital

3. Transformasi digital

Transformasi digital mencakup penggunaan dan kemampuan transformatif dalam hal menginformasikan kesadaran digital. Tahap transformasi adalah tahap penggunaan proses digital yang memungkinkan inovasi dan kreativitas dalam suatu produk digital tertentu, bukan hanya meningkatkan saja, tetapi juga mendukung metode tradisional.

Faktor-faktor yang menyebabkan terjadinya transformasi digital adalah perubahan regulasi atau aturan, adanya perubahan pada lansekap persaingan, adanya pergeseran atau perubahan ke bentuk digital dari industri, adanya perubahan perilaku dan harapan konsumen, adanya pemahaman akan manfaat teknologi digital, dan kesiapan sumber daya (Adiningsih, 2019).

Akhirnya, transformasi digital ini digambarkan sebagai total dan keseluruhan efek digitalisasi di masyarakat. Khan mengatakan bahwa digitasi telah memungkinkan proses digitalisasi, yang mendorong peluang lebih kuat untuk bertransformasi dan mengubah modal bisnis yang ada, sosial-struktur ekonomi, hukum dan langkah-langkah kebijakan, pola organisasi, hambatan budaya, dan lain-lain. 
Digitasi (konversi), digitalisasi (proses) dan transformasi digital (efek) mempercepat dan menerangi apa yang sudah ada dan sedang berlangsung secara horizontal dan prosesproses perubahan global dalam masyarakat.

\section{Konsep Menghimpun}

Menghimpun adalah proses, cara, perbuatan mengumpulkan, penghimpunan, pengerahan. Menghimpun dana adalah sebuah proses dalam menggalang dana bukan hanya meminta uang, melainkan juga menjual ide dan meyakinkan pemberi, bahwa memberi bantuan kepada yang membutuhkan akan memberikan perubahan kepada masyarakat, dengan demikian pemberi akan dengan rela menerima ide dan bersedia menyumbangkan hartanya untuk kepentingan masyarakat secara luas.

Tujuan menghimpun wakaf adalah menggalang dana sosial, mentransformasikan tabungan sosial menjadi modal sosial, mengembangkan investasi sosial, menyisihkan sedikit keuntungan orang kaya sebagai bentuk tanggung jawab mereka terhadap masyarakat sekitar, mengintegrasikan keamanan sosial dan kedamaian sosial serta meningkatkan kesejahteraan umat (Kasdi et al, 2014).

\section{Urgensi Wakaf}

Secara etimologi, kata "Wakaf" berasal dari bahasa Arab "Waqafa". Asal kata "Waqafa" berarti "menahan" atau "berhenti" atau "diam" di tempat" atau tetap berdiri". Kata "Waqafa-Yaqufu-Waqfan" sama artinya "Habas-Yahbisu-Tahbisan". Kata al-Waqf dalam bahasa Arab mengandung beberapa pengertian. Artinya menahan, menahan harta untuk diwakafkan, tidak dipindah milikkan (Hujriman, 2018).

Wakaf juga bermakna menyerahkan sesuatu yang menjadi miliknya kepada orang atau badan lembaga untuk dipelihara dan dimanfaatkan (Berkah et al, 2020).

Para ulama memiliki pandangan yang berbeda tentang defenisi dari wakaf. Faishal Haq berpendapat bahwa perbedaan definisi wakaf oleh para ulama madzhab dikarenakan wakaf mempunyai 25 arti lebih, meski yang lazim dipakai adalah arti menahan dan mencegah. Arti-arti yang banyak ini mempengaruhi para mujtahid dalam menetapkan definisi wakaf (Haq \& Anam, 1993).

Para ahli fiqih berbeda dalam mendefinisikan wakaf menurut istilah, sehingga mereka berbeda dalam memandang hakikat wakaf itu sendiri. Berbagai pandangan tentang wakaf menurut istilah sebagai berikut :

\section{a. Wakaf Menurut Abu Hanifah}

Wakaf adalah menahan suatu benda yang menurut hukum, tetap di wakif dalam rangka mempergunakan manfaatnya untuk kebajikan. Berdasarkan definisi itu maka pemilikan harta wakaf tidak lepas dari wakif, bahkan ia dibenarkan menariknya kembali dan ia boleh menjualnya. Jika si wakif wafat, harta tersebut menjadi harta warisan buat ahli warisnya. Jadi yang timbul dari wakaf hanyalah "menyumbangkan manfaat". Karena itu mazhab Hanafi mendefinisikan wakaf adalah : "Tidak melakukan suatu tindakan atas suatu benda, yang berstatus tetap sebagai hak milik, dengan menyedekahkan manfaatnya kepada suatu pihak kebajikan (sosial), baik sekarang maupun akan datang".

\section{b. Wakaf Menurut Maliki}

Mazhab Maliki berpendapat bahwa wakaf itu tidak melepaskan harta yang diwakafkan dari kepemilikan wakif, namun wakaf tersebut mencegah wakif melakukan tindakan yang dapat melepaskan kepemilikannya atas harta tersebut kepada yang lain dan wakif berkewajiban menyedekahkan manfaatnya serta tidak boleh menarik kembali wakafnya. Perbuatan wakif menjadi manfaat hartanya untuk digunakan oleh mustahiq (penerima wakaf), walaupun yang dimilikinya itu berbentu upah, atau menjadikan hasilnya untuk dapat digunakan seperti mewakafkan uang. Wakaf dilakukan dengan mengucapkan lafadz wakaf untuk masa tertentu susuai dengan keinginan pemilik. Dengan kata lain, pemilik 
harta menahan benda itu dari penggunaan secara pemilikan, tetapi membolehkan pemanfaatan hasilnya untuk tujuan kebaikan, yaitu memberikan manfaat benda secara wajar sedang itu tetap menjadi milik wakif. Perwakafan itu berlaku untuk suatu masa tertentu, dan karenanya tidak boleh disyaratkan sebagai wakaf kekal (selamanya).

c. Wakaf Menurut Syafi'I dan Ahmad bin Hambal

Syafi'i dan Ahmad berpendapat bahwa wakaf adalah melepaskan harta yang diwakafkan dari kepemilikan wakif, setelah sempurna prosedur perwakafan. Wakif tidak boleh melakukan apa saja terhadap harta yang diwakafkan, seperti : perlakuan pemilik dengan cara pemilikannya kepada yang lain, baik dengan tukaran atau tidak. Jika wakif wakaf, harta yang diwakafkan tersebut tidak dapat diwarisi oleh warisnya. Wakif menyalurkan menfaat harta yang diwakafkannnya kepada mauquf'alaih (yang diberi wakaf) sebagai sedekah yang mengikat, dimana wakif tidak dapat melarang penyaluran sumbangannya tersebut. Apabila wakif melarangnya, maka Qadli berhak memaksa agar memberikannya kepada mauquf'alaih. Karena itu mazhab Syafi'i mendefinisikan wakaf adalah : "tidak melakukan suatu tindakan atas suatu benda, yang berstatus sebagai milik Allah SWT, dengan menyedekahkan manfaatnya kepada suatu kebajikan (sosial)"

Paparan para ulama memiliki sebuah makna bahwa tujuan wakaf adalah sebagai sarana ibadah sosial yang diperintahkan agama. Setiap Muslim yang memiliki harta kekayaan dianjurkan untuk mewakafkan hartanya sesuai dengan syarat yang telah ditetapkan syariat (Hidayatullah, 2016).

Prinsip pemilikan harta dalam ajaran Islam menyatakan bahwa harta tidak dibenarkan hanya dikuasai oleh sekelompok orang, karena akan melahirkan eksploitasi kelompok minoritas (si kaya) terhadap kelompok mayoritas (si miskin) yang akan menimbulkan kegoncangan sosial dan akan menjadi penyakit masyarakat yang mempunyai akibat-akibat negatif yang beraneka ragam.

Menurut Abdul Nasir Khoerudin wakaf sebagai pranata sosial memiliki tiga hal yaitu wakaf sebagai lembaga keagamaan, yang sumber datanya meliputi: Quran, Sunnah, dan Ijtihād. Wakaf sebagai lembaga yang diatur oleh negara, yang merujuk pada peraturan perundang-undangan yang berlaku di negara itu, dan wakaf sebagai lembaga kemasyarakatan atau suatu lembaga yang hidup di masyarakat berarti mengkaji wakaf dengan tinjauan sosial yang meliputi fakta dan data yang ada dalam masyarakat Indonesia (al-Zuhaili, 2014).

\section{Dasar Hukum Wakaf}

1. Al-Qur'an

Wakaf tidak secara eksplisit disebutkan dalam Al-Qur'an, namun wakaf diilhami oleh ayat-ayat Al-Qur'an tertentu. Diantaranyaa adalah Surat Al-Baqarah (2) ayat 261 (Soemitra, 2010).

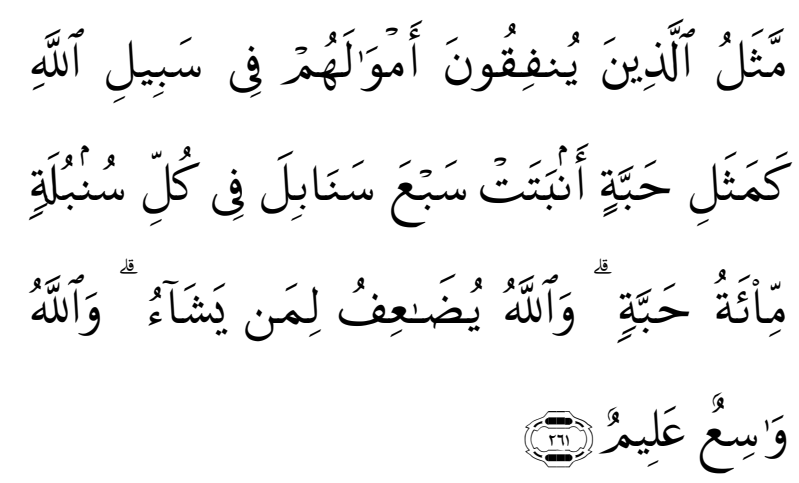

Artinya: "Perumpamaan (nafkah yang dikeluarkan oleh) orang-orangyang menafkahkan hartanya di jalan Allah adalah serupa dengan sebutirbenih yang menumbuhkan tujuh bulir, pada tiap-tiap bulir seratus biji. Allah melipat gandakan (ganjaran) bagi siapa yang Dia kehendaki. Dan Allah Maha Luas (karunia-Nya) lagi Maha Mengetahui."(Q.S. Albaqarah ayat 261).

\section{Hadist}

Selain Al-Qur'an yang dijadikan sebagai rujukan dalam mengamalkan wakaf, 
terdapat pula hadits yang dijadikan dasar mengamalkan wakaf :

Artinya : "Dari Abu Hurairah ra. Sesungguhnya Rasulullah Saw bersabda: Apabila manusia mati, maka terputuslah amalannya, kecuali tiga perkara : sedekah jariyah, ilmu yang bermanfaat dan anak saleh yang mendoakannya. (H.R. Muslim).

Hadits Nabi yang secara tegas menyinggung dianjurkannya ibadah wakaf, yaitu perintah Nabi kepada Umar untuk mewakafkan tanahnya yang ada di Khaibar :

Artinya : "Dari Ibnu Umar ra. Berkata, bahwa sahabat Umar R.a. Memperoleh sebidang tanah di Khaibar kemudian menghadap kepada Rasulullah untuk mmemohon petunjuk. Umar berkata : Ya Rasulullah, saya mendapatkan sebidang tanah di Khaibar, saya belum pernah mendapatkan harta sebaik itu, maka apakah engkau perintahkan kepadaku? Rasulullah menjawab : Bila kamu suka, kamu tahan (pokoknya) tanah itu, dan kamu sedekahkan (hasilnya). Kemudian

Umar menyedekahkannya kepada orang-orang fakir, kaum kerabat, budak belian, sabilillah,ibnu sabil dan tamu. Dan tidak mengapa atau tidak dilarang bagi yang menguasai tanah wakaf itu (pengurusnya) makan dari hasilnya dengan cara yang baik.

\section{Rukun Wakaf}

Rukun Wakaf Ada empat rukun yang mesti dipenuhi dalam berwakaf. Pertama, orang yang berwakaf (al-waqif). Kedua, benda yang diwakafkan (al-mauquf). Ketiga, orang yang menerima manfaat wakaf (almauquf 'alaihi). Keempat, lafadz atau ikrar wakaf (sighah) (Sari, 2006).

\section{Syarat-Syarat Wakaf}

1. Syarat-syarat orang yang berwakaf (alwaqif)

Syarat-syarat al-waqif ada empat. Pertama, orang yang berwakaf ini mestilah memiliki secara penuh harta itu, artinya dia merdeka untuk mewakafkan harta itu kepada sesiapa yang ia kehendaki. Kedua, dia mestilah orang yang berakal, tak sah wakaf orang bodoh, orang gila, atau orang yang sedang mabuk. Ketiga, dia mestilah baligh. Dan keempat, dia mestilah orang yang mampu bertindak secara hukum (rasyid). Implikasinya orang bodoh, orang yang sedang muflis dan orang lemah ingatan tidak sah mewakafkan hartanya.

2. Syarat-syarat harta yang diwakafkan (almauquf)

Harta yang diwakafkan itu tidak sah dipindah milikkan, kecuali apabila ia memenuhi beberapa persyaratan yang ditentukan; Pertama, barang yang diwakafkan itu mestilah barang yang berharga. Kedua, harta yang diwakafkan itu mestilah diketahui kadarnya. Jadi apabila harta itu tidak diketahui jumlahnya (majhul), maka pengalihan milik pada ketika itu tidak sah. Ketiga, harta yang diwakafkan itu pasti dimiliki oleh orang yang berwakaf (wakif). Keempat, harta itu mestilah berdiri sendiri, tidak melekat kepada harta lain (mufarrazan) atau disebut juga dengan istilah (ghaira shai').

3. Syarat-syarat orang yang menerima manfaat wakaf (al-mauquf alaih)

Dari segi klasifikasinya orang yang menerima wakaf ini ada dua macam, pertama tertentu (mu'ayyan) dan tidak tertentu (ghaira mu'ayyan). Yang dimasudkan dengan tertentu ialah, jelas orang yang menerima wakaf itu, apakah seorang, dua orang atau satu kumpulan yang semuanya tertentu dan tidak boleh dirubah. Sedangkan yang tidak tentu maksudnya tempat berwakaf itu tidak ditentukan secara terperinci, umpamanya seseorang sesorang untuk orang fakir, miskin, tempat ibadah, dan lain-lain. Persyaratan bagi orang yang menerima wakaf tertentu ini (al-mawquf mu'ayyan) bahwa ia mestilah orang yang boleh untuk memiliki harta (ahlan li al-tamlik), maka orang muslim, merdeka dan kafir zimmi yang memenuhi syarat ini boleh memiliki harta wakaf. Adapun orang bodoh, hamba 
sahaya, dan orang gila tidak sah menerima wakaf. Syarat-syarat yang berkaitan dengan ghaira mu'ayyan; Pertama, ialah bahwa yang akan menerima wakaf itu mestilah dapat menjadikan wakaf itu untuk kebaikan yang dengannya dapat mendekatkan diri kepada Allah SWT. Dan wakaf ini hanya ditujukan untuk kepentingan Islam saja.

4. Syarat-syarat Shigah berkaitan dengan isi ucapan (sighah) perlu ada beberapa syarat. Pertama, ucapan itu mestilah mengandung kata-kata yang menunjukkan kekalnya (ta'bid). Tidak sah wakaf kalau ucapan dengan batas waktu tertentu. Kedua, ucapan itu dapat direalisasikan segera (tanjiz), tanpa disangkutkan atau digantungkan kepada syarat tertentu. Ketiga, ucapan itu bersifat pasti. Keempat, ucapan itu tidak diikuti oleh syarat yang membatalkan. Apabila semua persyaratan diatas dapat terpenuhi maka penguasaan atas tanah wakaf bagi penerima wakaf adalah sah. Pewakaf tidak dapat lagi menarik balik pemilikan harta itu telah berpindah kepada Allah dan penguasaan harta tersebut adalah orang yang menerima wakaf secara umum ia dianggap pemiliknya tapi bersifat ghaira tammah (Soemitra, 2010).

\section{Profil BWI}

Badan Wakaf Indonesia (BWI) adalah lembaga negara independen yang dibentuk berdasarkan Undang-Undang Nomor 41 Tahun 2004 tentang wakaf. Badan ini dibentuk dalam rangka mengembangkan dan memajukan perwakafan di Indonesia. BWI dibentuk bukan untuk mengambil alih aset-aset wakaf yang selama ini dikelola oleh nazhir (pengelola aset wakaf) yang sudah ada.

BWI hadir untuk membina nazhir agar aset wakaf dikelola lebih baik dan lebih produktif sehingga bisa memberikan manfaat lebih besar kepada masyarakat, baik dalam bentuk pelayanan sosial, pemberdayaan ekonomi, maupun pembangunan infrastruktur publik.
BWI berkedudukan di ibukota Negara dan dapat membentuk perwakilan di provinsi, kabupaten, dan/atau kota sesuai dengan kebutuhan.

Anggota BWI diangkat dan diberhentikan oleh Presiden. Masa jabatannya selama 3 tahun dan dapat diangkat kembali untuk satu kali masa jabatan. Jumlah anggota BWI 20 sampai dengan 30 orang yang berasal dari unsur masyarakat. Anggota BWI periode pertama diusulkan oleh Menteri Agama kepada Presiden. Periode berikutnya diusulkan oleh panitia seleksi yang dibentuk BWI. Adapun anggota perwakilan BWI diangkat dan diberhentikan oleh BWI.

Struktur kepengurusan BWI terdiri atas Dewan Pertimbangan dan Badan Pelaksana. Masing-masing dipimpin oleh seorang ketua yang dipilih dari dan oleh para anggota. Badan Pelaksana merupakan unsur pelaksana tugas, sedangkan Dewan Pertimbangan adalah unsur pengawas.

\section{METODE PENELITIAN}

Penelitian pada metode ini menggunakan Penelitian Kepustakaan (Library Research) dan yang di jadikan sebagai data primer dalam penelitian ini yakni data yang di peroleh langsung dari sumber utama yaitu buku-buku mengenai transformasi digital wakaf BWI dalam menghimpun wakaf di era digitalisasi. Metode pengumpulan data yang digunakan penulis yakni deskriptif. Kajian ini akan mengkaji lebih jauh tentang transformasi digital wakaf BWI dalam menghimpun wakaf di era digitalisasi.

\section{HASIL DAN PEMBAHASAN}

\section{Urgensi Transformasi dan Sasaran Digital Wakaf BWI}

Revolusi industri 4.0 merupakan keniscayaan dan peluang yang tidak perlu diperdebatkan lagi tapi perlu di raih. Dunia usaha dan perusahaan perlu bergerak cepat agar gelombang revolusi industri ini dapat dikuasai menjadi peluang untuk kemajuan dan kesejahteraan bangsa (Albert, 2020). 
Era digitalisasi ditandai dengan maraknya penggunaan teknologi dengan mengurangi peran manusia dalam pengerjaannya namun terbukti lebih efektif dan efesien dalam mencapai tujuan organisasi. Penghimpunan dana wakaf merupakan bagian fundraising menggunakan teknologi guna memanjakan wāqif. Fundraising adalah istilah lain dalam penghimpunan dana wakaf dimana kegiatan ini merupakan proses mempengaruhi calon wakif agar mau berwakaf.

Inovasi teknologi telah mendorong fenomena digitalisasi di berbagai bidang, termasuk dalam perwakafan. Untuk itu, sebagai upaya mempercepat transformasi wakaf produktif, pengelolaan wakaf harus memanfaatkan teknologi dan platform digital. Pemanfaatan teknologi dan platform digital dalam pengelolaan wakaf juga harus didorong mulai dari tahap pengumpulan sampai pelaporan pemanfaatan wakaf. Digitalisasi wakaf, baik untuk mobilisasi dana sosial publik, seperti wakaf tunai dan wakaf berbasis sukuk, maupun pengelolaan aset secara produktif akan dapat lebih efektif, efisien, dan transparan.

Hal penting lainnya yakni peningkatan pemahaman dan kesadaran berwakaf melalui sosialisasi, literasi dan edukasi juga perlu diperbaiki dengan memanfaatan teknologi dan platform digital. Terutama dalam menjangkau generasi milenial yang sehari-hari akrab dengan teknologi digital. Untuk itu, literasi dan edukasi wakaf perlu dikembangkan dalam berbagai platform media sosial secara kontinyu dan dengan narasi yang mudah dipahami oleh masyarakat. Sampai saat ini, data literasi wakaf di Indonesia masih termasuk kategori rendah dengan score 50,48, lebih rendah dari literasi zakat yang masuk dalam kategori sedang dengan score 66,78.

\section{Analisis Transformasi Digital Wakaf BWI}

Badan Wakaf Indonesia (BWI) terus berupaya mengembangkan aplikasi untuk mendukung waqf digital guna mengelola potensi besar wakaf secara nasional dengan memanfaatkan teknologi digital.

Pengembangan

perwakafan merupakan bagian dari pengembangan dana sosial syariah di tanah air. Pada tanggal 1 Juli 2021 lalu Badan Wakaf Indonesia (BWI) meluncurkan e-services untuk para nazhir di Indonesia dalam bentuk layanan elektronik untuk pendaftaran nazhir. Layanan ini diluncurkan sebagai bagian dari fase kedua dari tahapan proses transformasi digital yang dilakukan oleh BWI untuk memperkuat ekosistem pembangunan wakaf nasional.

Pada peluncuran e-services tersebut, Ketua BWI Prof. Mohamad Nuh menegaskan komitmen BWI untuk mendorong penguatan transformasi digital sebagai bagian penting dari upaya optimalisasi potensi wakaf, sekaligus meningkatkan kesadaran masyarakat untuk mau berwakaf. Selain itu, dengan komposisi penduduk Indonesia yang 52 persennya adalah generasi milenial dan generasi Z, maka pilihan digitalisasi merupakan langkah strategis yang harus diambil oleh BWI.

Secara umum, ada tiga tahapan proses transformasi digital yang dilakukan BWI yaitu :

Pertama, penguatan digitalisasi internal BWI. Hal ini ditandai dengan tiga indikator utama, yaitu peluncuran platform berkahwakaf.id, platform media sosial sahabatbwi.com dan layanan e-services untuk pendaftaran nazhir. Untuk dua platform awal, telah diluncurkan pada 10 April 2021 lalu, tiga hari menjelang puasa Ramadan 1442 H. Tujuannya adalah untuk semakin memudahkan masyarakat dalam berwakaf, khususnya wakaf uang dan wakaf melalui uang, mendorong penguatan kampanye dan edukasi wakaf masyarakat, serta untuk meningkatkan layanan bagi para nazhir sehingga proses pendaftaran nazhir dapat dilaksanakan dengan lebih cepat, efisien, namun tetap selaras dengan ketentuan yang berlaku.

Kedua, yang dilakukan BWI adalah memperkuat digitalisasi nazhir dan integrasi 
data wakaf. Dalam digitalisasi nazhir ini, yang menjadi fokus utamanya adalah memperkuat saluran digital fundraising wakaf uang dan wakaf melalui uang, serta mengembangkan sistim pelaporan yang kredibel dan reliable (dapat dipercaya).

Terkait dengan saluran pengumpulan digital, akan didorong proses integrasi dengan nazhir lain. Apabila nazhir tersebut telah memiliki platform pengumpulan digital sendiri, maka akan didorong agar platform tersebut bisa terkoneksi dengan platform berkah wakaf yang telah dikembangkan BWI. Sebaliknya, apabila nazhir tersebut belum memiliki platform sendiri, maka dapat memanfaatkan pula platform berkah wakaf yang ada. Terkait dengan hal ini, BWI perlu menyusun aturan dan mekanismenya sehingga integrasi data penghimpunan wakaf uang dan wakaf melalui uang bisa dilakukan dengan baik.

Selanjutnya, aspek pelaporan adalah hal yang sangat krusial. Laporan yang kredibel akan memengaruhi kualitas database perwakafan yang ada. Harus diakui bahwa salah kelemahan fundamental dalam sistem perwakafan hari ini sangat terkait dengan ketersediaan data yang handal. Untuk itu, laporan yang disampaikan oleh para nazhir harus dapat dipastikan valid, terukur, tepat waktu dan terverifikasi dengan baik.

\section{Dengan}

digitalisasi

yang

dikembangkan BWI, diharapkan kecepatan, ketepatan, dan kehandalan laporan para nazhir dapat ditingkatkan dari waktu ke waktu. Disinilah kualitas layanan e-reporting untuk nazhir, yang akan dikembangkan BWI, memegang peranan yang sangat penting.

Selain itu, integrasi data wakaf juga perlu dilakukan dengan sistem pendataan yang telah lebih dulu ada, khususnya Sistem Informasi Wakaf (SIWAK) yang dikembangkan Kementerian Agama, maupun sistem yang ada di BPN (Badan Pertanahan Nasional). Integrasi data SIWAK Kemenag dan sistem di BPN sangat penting, agar efisiensi dan efektivitas proses sertifikasi wakaf tanah dapat ditingkatkan. Demikian pula halnya dengan integrasi data wakaf uang yang terkumpul di LKSPWU yang dapat menghasilkan informasi yang bersifat real time dan valid. Dengan adanya integrasi ini, maka sejumlah resiko yang mungkin timbul dari kelemahan data yang ada, seperti resiko hukum dan resiko reputasi, dapat diminimalisir dengan baik.

Pada tahap ketiga, yang akan dilakukan adalah mengakselerasi penguatan ekosistem digital dan pengembangan inovasi model pengelolaan wakaf secara digital. Pada tahap ini, seluruh pemangku kepentingan strategis (strategic stakeholders) perwakafan telah terkoneksi dengan baik. Inovasi model pengelolaan wakaf dapat terus dikembangkan, seperti diterbitkannya DES (Daftar Efek Syariah) khusus saham-saham syariah yang diwakafkan. Saat ini belum memungkinkan, tapi ke depan, siapa tau DES Wakaf ini bisa dikembangkan. Ini terjadi ketika kesadaran para investor untuk mewakafkan saham yang dimilikinya semakin besar.

Dengan demikian, Badan Wakaf Indonesia (BWI) telah terus berupaya transformasi digital wakaf guna mengembangkan aplikasi untuk mendukung waqf digital. Kepercayaan publik diyakini akan semakin meningkat karena digitalisasi yang tepat akan meningkatkan transparansi dan akuntabilitas sistem wakaf. Untuk itu, pemanfaatan teknologi blockchain dalam proses transformasi digital ini menjadi sangat penting dan strategis. Kepercayaan inilah yang akan membuat realisasi penerimaan wakaf nasional akan semakin meningkat. Dan yang juga tidak boleh diabaikan, program pengelolaan aset wakaf beserta penyaluran manfaat kepada para mauquf 'alaih harus terus diperbaiki dan ditingkatkan kualitasnya. Tujuannya agar publik semakin teryakinkan dan memiliki referensi yang kuat akan program-program yang dilakukan oleh para nazhir. Ketika publik melihat bahwa setiap rupiah yang diwakafkannya memberikan manfaat yang 
besar, baik dalam hal penurunan kemiskinan maupun peningkatan kesejahteraan masyarakat, maka mereka akan semakin termotivasi dan tergerak untuk berwakaf dan menjadikannya sebagai bagian dari gaya hidup (life style). Karena itulah, desain program wakaf, baik yang menggunakan pendekatan sosial maupun pendekatan komersial (wakaf produktif) perlu untuk dikembangkan secara inovatif, dengan tetap menjaga relevansinya dengan pemenuhan kebutuhan masyarakat.

\section{KESIMPULAN}

Berdasarkan dari uraian di atas, dapat di tarik kesimpulan bahwa Badan Wakaf Indonesia (BWI) terus berupaya bertransformasi mengembangkan aplikasi untuk mendukung waqf digital guna mengelola potensi besar wakaf secara nasional dengan memanfaatkan teknologi digital. Tiga langkah strategis dalam upaya optimalisasi potensi wakaf yaitu: penguatan digitalisasi internal BWI, memperkuat digitalisasi nazhir dan integrasi data wakaf, mengakselerasi penguatan ekosistim digital dan pengembangan inovasi model pengelolaan wakaf secara digital. Dengan memaksimalkan upaya melalui tiga tahapan di atas, diharapkan ekosistim digital wakaf akan semakin fleksibel, membesar dan menguat, serta memberikan dampak multiplier terhadap perekonomian nasional.

\section{DAFTAR PUSTAKA}

Adiningsih, Sri. 2019. Transformasi Ekonomi Berbasis Digital di Indonesia. PT. Gramedia Pustaka Utama. Jakarta.

Albert, Manerep Pasaribu. 2020. Strategi dan Transformasi Digital. PT.Gramedia. Jakarta.

Al-Zuhaili, Wahbah. 1985.Al-Fiqh al-Islāmî WaAdillatuhu. Dār al-Fikr. Bireut.

Badan Wakaf Indonesia. 2009 .Manajemen Fundraising dalam Penghimpunan Dana Wakaf. Dipetik November 28, 2020, dari https://www.bwi.go.id/297/2009/01/06 /manajemfundraising-dalampenghimpunan-danawakaf/

Barkah, Qodariah., Azwari, Peny Cahaya., Saprida., \& Umari, Zuul Fitriani. 2020. Fikih Zakat, Sedekah, dan Wakaf. Kencana. Jakarta.

Fauzia, Amelia., Almuin, Nani., Rohayati, Tati., \& Garadian, Endi Aulia. 2019. Fenomna Wakaf di Indonesia, Tantangan Menuju Wakaf Produktif. Badan Wakaf Indonesia. Jakarta.

Haq, Faishal., \& Anam, H. A. Saiful. 2002. Hukum Wakaf dan Perwakafan di Indonesia. PT. Garoeda Buana Indah. Pasuruan.

Hidayatullah, Syarif. 2016. Wakaf Uang Dalam Perspektif Hukum Islam dan Hukum Positif di Indonesia. SALAM : Jurnal Sosial \& Budaya Syar-i , 3(1), p. 1-20.

Hujriman. 2018. Hukum perwakafan di Indonesia. Deepublish. Yogyakarta.

IBTimes.ID. 2020. Data Populasi Penduduk Muslim 2020: Indonesia Terbesar di Dunia. Dipetik Desember 1, 2021, dari : https://ibtimes.id/data-populasipendudukmuslim-2020-indonesiaterbesar-di-dunia/.

Kasdi, Abdurrahman., Moerdiyanto., \& Zuha, Abu. 2014. Permberdayaan Wakaf Produktif Berbasis Wirausaha. Idea Pres. Yogyakarta.

M Paksi, Gerindra., Manzilati, Asfi., \& Ekawaty, Marlina. 2020. Wakaf Bergerak Teori dan Praktik di Asia. IKAPI. Malang.

Sari, Elsi Kartika. 2006. Pengantar Hukum Zakat dan Wakaf. PT. Grasindo. Jakarta.

Soemitra, Andri. 2010. Bank dan Lembaga Keuangan Syariah. Kencana. Jakarta. 